International Congress held at the Sorbonne under the auspices of the Union Internationale contre le Cancer, the first of the series to be held in France. He was a member of many foreign academies and honorary doctor of numerous universities. $\mathrm{He}$ was Commander of the Légion d'Honneur and Grand Officier of the National Order of Merit.

Professor Lacassagne was primarily a pathologist, but his work ranged widely to include experimental radiopathology and endocrine carcinogenesis. He was also a pioneer of the new and developing subject of radiobiology. From the close of the First World War he collaborated actively with Regaud in that fundamental work which rapidly led to a scheme of treatment of cancer in man, by $\mathrm{X}$-rays, radium and radioactive isotopes, and was foremost in the development of autoradiography. With the physicist, Fernand Holweck, he continued the study of the fundamentals of radiology, especially through the use of microorganisms, and pursued this work further with Wollman. From 1929 with $R$. Vinzent and others, Lacassagne made a study of the carcinogenic response of infected foci following irradiation. In 1932 came the discovery of the role of oestrogens in causing cancer of the breast in male mice, an observation which greatly stimulated endocrine carcinogenesis and was the forerunner of the successful treatment of carcinoma of the prostate with oestrogens.

From 1943 he took a leading part, inspired by the work of Otto Schmidt, in attempts to relate the biological activity of the carcinogenic hydrocarbons to the molecular distribution of $\pi$ electrons with the collaboration of $P$. and R. Daudel, A. and B. Pullman, N. G. Buu-Hoï, G. Rudali and F. Zajdela.

Professor Lacassagne was a true savant and humanitarian, whose worldwide influence will be greatly missed.

\section{Professor Aleksandr G. Vologdin}

Aleksandr Grigorevich Vologdin, one of Russia's leading palaeontologists and geologists, died on September 28, 1971, aged 75, after a long illness.

Vologdin was born on March 11 , 1896. He was educated at the Leningrad Institute of Mining, from which he graduated in 1925. His activity in geology began, however, prior to his graduation--from 1920 onwards, he served on the Geological Committee of the USSR, and remained associated with this and subsidiary institutions until 1943.

He became a specialist in the geology and stratigraphy of Siberia and the Asian regions of the USSR. At first his main concern was prospecting for mineral resources, but this work led to an ever-growing interest in the palaeontology of the region, particularly that of the Cambrian strata.

From 1931 to 1966 , he published a number of definitive papers and monographs on the archaeocyaths found in these areas. These works include: Archaeocyaths of Siberia (1931), Archaeocyaths and Water-Plants of the Cambrian Limestones of Mongolia and Tuva, New Data on the Archaeocyaths of Siberia (1959), Three Types of Archaeocyaths from the Siberian Cyath Lower Cambrian Zone of the Baikal Uplands (1959), Stromatoliths and Phototropism (1963), Discovery of Triple-axial Symmetry in Cambrian Archaeocyaths (1966).

He also published detailed geological surveys of the Tubinskii-Sisim and Kizir-Kazyrskii Regions and of Northern Bukovina and Bessarabia.

In 1939, he became a corresponding member of the Academy of Sciences of the USSR, and in 1943, an associate of the Institute of Palaeontology of the Academy. He worked in association with the leading Soviet geological and mineralogical bodies, including the AllUnion Aero-geological Trust, the Institute of the Petroleum and Gas Industries, Moscow State University and the Soviet Ministry of Geology.

\section{Announcements}

\section{Appointments}

Sir Alastair Pilkington has been appointed to the Science Research Council in succession to Mr D. L. Nicolson.

Professor C. A. Coulson has been made president of the Institute of Mathematics and its Applications. The new vicepresident of the Institute is Professor Heini Halberstam.

\section{Miscellaneous}

The CIBA medal and prize of the Biochemical Society has been awarded to Dr D. H. Northcote, University of Cambridge, for his structural and biochemical studies on the formation of the cell walls of plants. The Colworth medal of the Society has been won by Dr Alan R. Williamson, National Institute for Medical Research, Mill Hill, for his work on gamma-globulin synthesis.

The Society of Pharmacological and Environmental Pathologists was founded in October 1971 to foster the discipline of pharmacological and environmental pathology, to contribute to the development of criteria and standards for the evaluation of pathological changes induced by drugs, chemicals or environmental pathologists, and to establish a registry of naturally occurring and induced diseases in laboratory animals. The president of the new society is Dr C. Hans Keysser. Those interested in the society are invited to write to the secretary-treasurer, Dr Howard A. Hartman, PO Box 276, Florham Park, New Jersey 07932, USA, for further information and forms of application for membership.

\section{HOW TO BUY NATURE}

Volumes start in January, March, May, July, September and November, but subscriptions may begin at any time.

The direct postal price per subscription is:

12 MONTHS * (52 issues per title)

$\begin{array}{lccc} & \begin{array}{c}\text { Surface mail } \\ \text { UK and } \\ \text { worldwide }\end{array} & \text { U.S.A. } & \text { Canada } \\ \text { Nature (Friday) } & \mathbf{£ 1 4} & \$ 48 & \$ 52 \\ \begin{array}{l}\text { Nature + } \\ \text { Nature Physical Science }\end{array} & £ 24 & \$ 83 & \$ 90 \\ \begin{array}{l}\text { Nature + } \\ \text { Nature New Biology }\end{array} & £ 24 & \$ 83 & \$ 90 \\ \text { All three editions } & \mathbf{£ 2 9 . 5 0} & \$ 108 & \$ 116 \\ \text { Annual tndex } & \mathbf{f 1} & \$ 3 & \$ 3\end{array}$

* Rates for shorter periods pro rata (minimum three months) (Charge for delivery by air mail on application)
Editorial and Publishing Offices of NATURE

MACMILLAN JOURNALS LIMITED

4 LITTLE ESSEX STREET, LONDON WC2R 3LF

Telephone Number : 01.8366633 . Telegrams : Phusis London WC2R 3LF Telex 262024

711 NATIONAL PRESS BUILDING WASHINGTON DC 20004

Telephone Number : 202-737 2355. Telex 64280 Subscription Department

MACMILLAN JOURNALS LIMITED

BRUNEL ROAD, BASINGSTOKE, HANTS

Telephone Number: Basingstoke 29242

American display advertisements

NATURE SCIENTIFIC PUBLICATIONS INC

711 NATIONAL PRESS BUILDING WASHINGTON DC 20004 All other advertisements

T. G. SCOTT \& SON, LIMITED

1 CLEMENT'S INN, LONDON WC2A 2ED

Telephone : 01-242 6264/01-405 4743

Telegrams : Textualist London WC2A 2ED

Registered as a newspaper at the Post Office

Copyright (C) Macmillan Journals Limited, February 41972 